\title{
ORGANIZATION OF THE PROJECT MANAGEMENT OFFICE OF SHIP REPAIR ENTERPRISE
}

\author{
Nikolai Fateev' ${ }^{1}$ Iryna Zaporozhets ${ }^{2}$
}

\begin{abstract}
The aim of the article is to study the features of ship repair production and, accordingly, develop recommendations for the composition of the functions of the project management office, its structure and stages of development. The characteristics of ship repair production, which determine its features and the structure of management of a ship repair enterprise, are systematically presented. The subject of the study is the models and methods of project management, programs and project portfolios of ship repair enterprises. The object of the study is the corporate project management system of a ship repair enterprise. The project-oriented nature of ship repair production, combined with a high degree of uncertainty in the planning and implementation of ship repair projects, identifies the need to use deterministic network models with a probabilistic estimate of the duration of work. To reduce risks in conditions of uncertainty, it is proposed to use Agile technologies, which organically complement the matrix organizational structure of a ship repair enterprise and ensure effective cooperation with the customer and the success of the business as a whole. The creation of a project management office is proposed to be implemented as a development system that includes four stages of maturity. The key functions of the project management office at each stage of development have been formulated. The role of the information model of the vessel in the implementation of the 6D design methodology, which provides monitoring during the operation of the vessel, predicting the degree of wear of the vessel's elements over time, is justified. The MS Project Standard package allows building interfaces with the information model of the vessel to obtain the parameters of the hull structures, characteristics of the mechanisms and equipment of the vessel, as well as recommendations for repair technology. An important function of the project management office is to participate in the strategic management of project portfolios. To implement this function in the enterprise management system, certain prerequisites for the development of portfolio management must be formed: a formalized strategy, metrics for evaluating projects for compliance with the strategy, a certain culture of management decisions. The duration of vessel repair determines the time of decommissioning. This important strategic indicator is the basis for the formulation of BS (balanced scorecard). An important task of the project management office is to implement feedback and provide information on the status of achieving the planned indicators at all levels of enterprise management. The structure of the function and tools of the project management office are determined by the management of the enterprise depending on the number and complexity of the ship repair projects, level of development of the corporate information system of the enterprise, availability of specialists with appropriate qualifications. The project management office will provide effective communication between project management and functional services of the enterprise, which will significantly improve the quality of the enterprise management system as a whole. The organization of the project management office in the management system of the ship repair enterprise will ensure the effective allocation of resources for projects, accounting for available resources of the enterprise, coordination of goals and tasks of individual projects with strategic plans of the enterprise. All this is aimed at reducing costs and increasing the competitiveness of the ship repair enterprise.
\end{abstract}

Key words: project, project management, project management office, ship repair production, information systems.

JEL Classification: M11, M15, O22

\footnotetext{
Corresponding author:

${ }^{1}$ Admiral Makarov National University of Shipbuilding, Ukraine.

E-mail: nikolay.fateev@nuos.edu.ua

ORCID: https://orcid.org/0000-0002-2663-6440

${ }^{2}$ Admiral Makarov National University of Shipbuilding, Ukraine.

E-mail: iryna.zaporozhets@nuos.edu.ua

ORCID: https://orcid.org/0000-0003-4015-5958

ResearcherID: U-4239-2017
} 


\section{Introduction}

Ship repair production is an important element of the system of operation of maritime and inland water transport. Increasing competition in global ship repair markets requires the constant improvement of technology and organization of production, development of modern management mechanisms. The main tasks that need to be addressed on the way to ensure the competitiveness of ship repair enterprises are reducing the duration of repairs, cost of work and improving the quality of repairs.

The theory and practice of project management have confidently become the basis of effective management mechanisms for ship repair enterprises. To enter the trajectory of sustainable development, ship repair enterprises use a strategy of diversification of production and economic activities, as well as resort to integration into the cluster economic systems of regional, national and international levels. At the same time, the network of production and corporate relations and dependencies is growing. In addition, there is a variability in the composition of cluster integrations and mobility of borders, which is necessary for effective functioning in a competitive environment. In these circumstances, the concept of project management in ship repair production must be supplemented with flexibility mechanisms that can be adapted to changes in internal and external factors, the structure of the project office must be brought in line with the industry specifics of project activities, which determines the relevance of the topic and content of the article.

The aim of this article is to study the features of ship repair production and, accordingly, develop recommendations for the composition, functions, structure of the project management office as a tool for strategic development in a competitive environment.

\section{Statement of the main research material}

A project management office is a balanced organizational and technological complex of software, technical and information tools and instruments aimed at implementing, supporting and improving the efficiency of project management processes. The functions of the project management office are performed within a unified information system and based on developed intracorporate standards (Bushuiev, Zakharov, Sharovara, 2009).
The PMBOK project management standard (American National Standard) recommends to define its functions in a wide range when organizing a project management office - from the functions of providing support in the management of individual projects to direct management of the enterprise project portfolio with integration into the mechanisms of strategic, tactical and operational management.

The PMBOK standard proposes a classification of the project management office into three types, depending on the degree of influence on the project activities of the enterprise:

1. Supportive - plays an advisory role, serves as a repository for projects, the degree of control from the project management office is low.

2. Supervising - provides support to the team of project managers, provides adaptation of models and methodologies of project management, analyzes successful practices.

3. Managing - supervises projects by directly management of the enterprise portfolio.The degree of control from the project management office is high.

Any type of project management office provides effective communication between projects and enterprise performance appraisal systems.

The nomenclature of functions of the project office of a ship repair enterprise and, accordingly, the architecture of software tools, it is advisable to form on the basis of an analysis of the features of ship repair production and strategic goals of the enterprise. The characteristics of ship repair production, which determine its features, can be presented in the following form:

- A high degree of uncertainty in the planning and implementation of ship repair projects (a significant part of the work is revealed after the dismantling of mechanisms and defects at later stages). It follows that the problem of relations with the customer, who needs a clear determination of the terms of repair in the contract, as well as the cost of all resources. Therefore, a specific form of cooperation with the customer has developed in ship repair, which provides for the readiness of all participants to change projects, their unification around common values.

- Single and small-scale production.

- Project-oriented nature of production. As a result, ship repair production has a pronounced matrix structure. At the same time, a strong matrix is inherent in ship repair, where project management 
factors prevail, project managers have broad powers.

- The irregularity of resource costs during the repair process, which in the context of multi-project management and a complex project portfolio structure requires the development of unique models for the supply of materials and components. - A significant proportion of manual operations, which, moreover, are performed in unfavorable conditions (seasonality, weather conditions), requires highly qualified personnel.

- Specific methods, tools and organization of production preparation, which significantly affects the duration and quality of repair projects. The ship's crew, representatives of the customer and the project executor take part in the preparation to repair the vessel. At this stage, flaw detection lists for all subsystems of the vessel (hull, mechanical, electrical, radio navigation, etc.) are compiled. Flaw detection lists include information on the nature of defects and comprehensive data on the range and scope of repair work, which are the basis for the development of a network model of a repair project.

- In work (Fateev, Zaporozhets, 2009), the authors set out the specifics of constructing the financial structure and budget system of a ship repair enterprise. Specific models for aggregating project budgets at the level of individual programs and the enterprise portfolio as a whole are proposed.

- In the process of preparation of ship repair production, a transport vessel as a technical system can be represented consisting of elements that have common design characteristics and repair technology. As a result of such a decomposition, a hierarchical structure is formed, where the lower level is made up of structural and technological elements (STE), for which standard technological repair processes are used. The results of work for each STE are completed with submission to the customer and, if necessary, to the classification society. The effectiveness of the ship repair process as a whole depends on the validity and quality of decomposition.

- When developing private network models for performing work for each STE in ship repair, it is necessary to use deterministic network models with a probabilistic estimate of the duration of work (Razu, 2007). In the process of linking private network models to the calendar and building an integrated network schedule for ship repair, a table of interdependence of work on different STE is used. After bringing the parameters of the network schedule to the specified constraints (optimization of the network schedule), a responsibility matrix is drawn up, which coordinates the structure of the breakdown of work on the project with the organizational structure of project management.

- The elements of the Agile methodology are increasingly used in ship repair (Kom Mayk. Agile, 2018; Appelo Yurgen, 2018). Through the formation of cross-functional teams, which include specialists from different divisions of the ship repair enterprise, as well as from suppliers, customers, consultants, etc., an efficient solution to conflict situations is provided for the distribution of resources between works on different STE. Agile technologies organically complement the matrix organizational structure of the ship repair enterprise, which provides effective cooperation with the customer, business success in a dynamic environment.

- Modern technologies for the design, construction, repair and operation of vessels are based on a single information space (6D design). Thus, models for planning and implementing the ship repair projects should be integrated with ship design systems.

It is advisable to implement the creation of a project management office as a developing project (Razu, 2007). Logically and temporally, the developing project consists of separate initiatives for further improvement and development of previously obtained results. The development of the organizational structure of the project office is individual for each individual enterprise. The set of tasks solved in the office directly correlates with the maturity of general management at the enterprise and project management, in particular.

We will present the structure and functions of the project office of a ship repair enterprise in the form of a developing system that includes several stages of maturity. The evolution of the project office is associated, first of all, with "increasing capacity", that is, the expansion of the set of functions performed by it. The proposed maturity levels are based on the model of classification of corporate project management systems recommended by the PMBOK standard (American National Standard) and taking into account the specifics of ship repair production.

Stage 1 - the processes of forming the project office as a structural unit of the enterprise: the development of regulations governing the activities of the project office, analysis of information on the 
structure of the project portfolio, formalization of project management processes.

An important element of the first stage is the formation of an information system for scheduling projects. In our opinion, the confident leader in the market of information systems for project management is the software product of Microsoft MS Project Standard (Microsoft Project, 2020). All the main tasks of planning and implementation of ship repair projects are implemented here.

The MS Project Standard package implements data export, i.e. import tools that provide integration with the enterprise accounting system. On the basis of this package, an automated workstation (AWS) is being formed for the project manager of a ship repair enterprise.

At the first stage, it is necessary to form and subsequently increase a knowledge base and skills in project management, to organize a continuous process of employee training.

Stage 2 involves expanding the influence of the project office by increasing the range of tasks. In addition to supporting the project management methodology in an active state, the project management office, through close interaction with project managers, ensures timely updating of project schedules in the information system, processes reports on the status of work on projects, which allows it to form an overall picture of projects, maintain a documented archive.

The financial structure of the ship repair enterprise is a system of responsibility centers. The budget system corresponds to the financial structure. The consolidated budget provides for the determination of indicators of the operating, investment and financial activities of the enterprise as a whole.The project management office provides analytical information on the costs of projects, programs and portfolios of the enterprise to the finance department and accounting.

The key function of the project management office at the second stage is to control the allocation of resources to projects. For this, the project management office forms a corporate pool of necessary materials, components and provides operational information to the material and technical supply service, which will allow to organize a reliable logistics service for the ship repair enterprise.

At stage 3, a predictive analytics function is recommended to the project management office, within the framework of which project statistics are maintained, analytical reports and normative estimates for project planning are generated.This also includes a register of typical risks associated with a high degree of uncertainty in ship repair production.

An important task of the third stage of project management office development is the development of regulations for information support of the Agile methodology. A cooperation of the project management office with cross-functional teams will allow to promptly adjust project plans, reallocate resources within the project portfolio.

The use of the information model of the vessel, which is formed at the stages of design and technological preparation of production within the methodology of $6 \mathrm{D}$-design, will reduce the complexity of the development of ship repair projects and improve their quality.

In essence, 6D-design allows planning for the next stages of life cycle of the vessel, it is a system of monitoring during operation of the vessel, predicting the degree of wear of ship elements over time. The project management office will provide preparation of documentation for scheduled inspections and tests of key units, repair and replacement of equipment, pipelines, mechanisms.

The MS Project Standard package allows to build effective interfaces for obtaining parameters of hull structures, characteristics of mechanisms and equipment of the vessel, as well as recommendations on repair technology, laid down in the information model of the vessel.

The stage 4 involves the active participation of the project management office in the strategic management of the project portfolio. To do this in the enterprise management system, certain prerequisites for the development of portfolio management must be formed: a formalized strategy, metrics for evaluating projects for compliance with the strategy, a certain culture of management decisions.

It is recommended to use the BS to assess the effectiveness of ship repair enterprise projects and their compliance with the corporate strategy. The BS evaluates the work of an enterprise on the basis of four balanced parameters: finance, customer relations, internal business processes, as well as training and advanced training of personnel. The duration of the vessel repair determines the terms of decommissioning. This important strategic indicator is the basis for formulating BS for all four groups. The task of the project management office is to implement feedback and provide information 
on the status of achieving the planned indicators at all levels of enterprise management.

The project management office, the level of development of which corresponds to the fourth stage, is not in demand at all ship repair enterprises. The structure, functions and tools of the project management office are determined by the management of the enterprise, depending on the number and complexity of ship repair projects, level of development of the corporate information system of the enterprise, and availability of trained specialists.

\section{Conclusions}

1. The features of ship repair production determine the structure, functions, composition of tools and stages of development of the project management office.

2. The organization of the project management office in the management system of the ship repair enterprise will ensure the effective allocation of resources for projects, accounting for available resources of the enterprise, coordination of goals and tasks of individual projects with strategic plans of the enterprise. All this is aimed at reducing costs and increasing the competitiveness of the ship repair enterprise.

3. The project management office will ensure effective communication of project management and functional services of the enterprise (marketing, material and technical supply, financial management, personnel management), which will improve the quality of the enterprise management system as a whole.

4. It is necessary to increase the knowledge base and skills in the management of ship repair projects, organize a continuous process of employee training.

5. For the sustainable development of project management methodology in shipbuilding and ship repair, it will be necessary to develop industry standards for project management.

\section{References:}

American National Standard. A Guide to the Project Management Body of Knowledge (PMBOK Guide). Sixth Edition. USA, ANSI/PMI, 2017.976 p.

Fateev, N. V., \& Zaporozhets, I. M. (2009). Byudzhetirovanie v sisteme uprableniya proektami i programami sudoremontnogo predpriyatiya [Budgeting in the project management system and programs of the ship repair enterprise]. Upravlinnia proektamy ta rozvytok vyrobnytstva, no. 2(30), pp. 118-123.

Razu, M. L. (2007). Upravlenie proektom. Osnovy proeknogo upravleniya [Project management. Fundamentals of project management]. Moscow: KNORUS, 767 p.

Kom Mayk. Agile. (2018). Otsenka i planirovanie proektov [Project evaluation and planning]. Moscow: Alpina, 245 p.

Bushuiev, S. D., Zakharov, A. M., \& Sharovara, O. M. (2009). Upravlinnia portfeliamy proektiv, prohramamy ta proektnym ofisom [Management of project portfolios, programs and project office]. Kyiv: KNUBA, 88 p.

Appelo Yurgen (2018). Agile-mededzhment. Lidersvo i upravlenie komandami [Agile Management: Leadership and Team Management]. Moscow: Alpina, $512 \mathrm{p}$.

Microsoft Project (2020). MS Project Standard. Avalable at: https://www.microsoft.com/uk-ua/ microsoft-365/project/project-management-software

Kaplan, R., \& Norton, D. (2016). Sbalansirovannaya sistema pokazateley. Ot strategii $k$ deystviyu [The Balanced Scorecard: Translating Strategy into Action]. Moscow: Olimp-Bisnes, 320 p. Avalable at: http://www.management.com.ua/books/view-books.php?id=72 